Esta obra está bajo una Licencia Creative Commons Atribución-NoComercial-Compartirlgual 4.0 Internacional

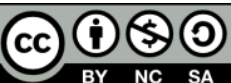

¿Te puedo sacar una foto?: Producción y circulación de imágenes digitales en el mundo artístico drag queen

María Daniela Brollo

DOI: https://doi.org/10.24215/16696581e266

\title{
¿Te puedo sacar una foto?: Producción y circulación de imágenes digitales en el mundo artístico drag queen
}

\section{Can I take a picture of you?: Production and circulation of images in the artistic world drag queen}

\author{
María Daniela Brollo danibrollo7@gmail.com \\ https://orcid.org/0000-0002-5595-5934
}

\section{Resumen}

Este artículo surge de una apuesta por indagar en el mundo artístico drag queen a partir de la pregunta por la relación entre los sujetos y las imágenes. Los usos de Internet y la creciente 
María Daniela Brollo ¿Te puedo sacar una foto?: Producción y circulación de imágenes digitales en el mundo artístico drag queen

circulación de imágenes digitales en las redes han modificado las lógicas de producción, visibilización y recepción de muchos universos sociales. El mundo artístico drag queen no es la excepción y en las últimas dos décadas, el circuito de fotografías en redes sociales virtuales como Facebook o Instagram ha transformado las prácticas y los intercambios entre sus protagonistas.

En el presente trabajo analizaré ese proceso de transformación, desde un abordaje etnográfico de la relación entre fotografías digitales y la práctica artística drag queen. El primer apartado del texto contiene una revisión introductoria de algunas aproximaciones dialógicas de la antropología al estudio de lo visual y las imágenes. Luego, un conjunto de notas sobre mi pesquisa etnográfica y finalmente el análisis de una serie de interacciones on-line y off-line entre las artistas y su público.

Palabras Clave: mundo artístico; imagen; fotografía; drag queen; redes sociales.

\section{Abstract}

This article arises from a commitment to investigate the world of drag queen art from the question of the relationship between subjects and images. The uses of the Internet and the growing circulation of digital images on the networks have modified the logic of production, visibility and reception of many social universes. The drag queen art world is no exception and in the last two decades, the circuit of photographs in virtual social networks such as Facebook or Instagram has transformed the practices and exchanges between its protagonists. In the present work I will analyze that transformation process, from an ethnographic approach of the relation between digital photographs and the drag queen artistic practice. The first section of the text contains an introductory review of some dialogical approaches of anthropology to the study of the visual and images. Then, a set of notes on my ethnographic research and finally the analysis of a series of on-line and off-line interactions between the artists and their audience.

Keywords: artistic world; image; photography; drag queen; social networks. 
María Daniela Brollo ¿Te puedo sacar una foto?: Producción y circulación de imágenes digitales en el mundo artístico drag queen

El espectáculo no es un conjunto de imágenes, sino una relación social entre personas mediatizada por imágenes (Guy Debord - La Sociedad del espectáculo)

¿Qué hacemos con las imágenes que nos hacen?

La experiencia humana se encuentra altamente mediatizada por lo visual y en la posmodernidad la circulación de imágenes se ha convertido en un fin en sí mismo (Mirzoeff, 2003). Los distintos medios digitales e interactivos de comunicación que funcionan en Internet modifican constantemente las subjetividades de los usuarios. En su libro Teoría de la imagen. Ensayos sobre representación verbal y visual, Mitchell (2009 [1994]) denominó como giro pictorial a una temporalidad que comienza en la segunda mitad del siglo XX y se extiende a la actualidad. Siguiendo el planteo del filósofo Richard Rortry, Mitchell propone que el giro pictorial sería un redescubrimiento de la imagen en un movimiento pos-lingüístico que incluye visualidad, discursos, cuerpos y aparatos. Estableciendo así un momento histórico donde las imágenes no quedarían atrapadas en un carácter de verdad basado en nociones positivistas o reducidas a los análisis de su reproducción por parte de los medios de comunicación masivos. Cabe entonces preguntarnos, con esta idea de giro como punto de partida inicial, qué hacemos desde las ciencias sociales con el lugar constitutivo que las imágenes ocupan en la experiencia humana.

Dado que se trata de un trabajo etnográfico me centraré en algunas discusiones que la antropología produjo sobre las dimensiones de lo visual y específicamente en aquellas que me habilitan herramientas analíticas para indagar en el objetivo de este artículo. Desde fines del siglo XIX la antropología organizó el conocimiento sobre la otredad a través de la observación y la exhibición de imágenes. Tal cual propone Carlos Masotta (1995), ya en 1876 y con una antropología naciente, teóricos influyentes como Edward Taylor remarcaban el aporte que la fotografía significó para las colecciones de los viajeros. En ese momento, los problemas de la representación dentro de la disciplina se vinculaban a prácticas coloniales de circulación de cierto tipo de imágenes de la otredad primitiva en forma de tarjetas postales, fotografías de viajes, ilustraciones, exhibiciones museográficas y exposiciones públicas. Desde entonces, las imágenes permanecieron vinculadas a la generación del exotismo fundante de la disciplina antropológica y más precisamente a la gestación del/la antropólogo/a como observador/a. Durante las décadas posteriores lo visual quedó atrapado en una relación unidireccional, ya que la antropología limitó principalmente sus debates en torno a la producción del cine 
etnográfico o a la utilización de la cámara como medio de registro del trabajo de campo, en un sentido metodológico pretendidamente neutral.

Desde la segunda mitad del siglo XX, crisis de la representación mediante, se produjeron nuevos planteos teórico-metodológicos sobre el vínculo entre antropología e imágenes aunque, tal cual propone Henley (2001), la discusión fue en general considerada una dimensión marginal de esta disciplina académica. Algunas propuestas como las de Ruby (2007) optaron por un enfoque más plural que consideró a los mundos visibles como procesos sociales de comunicación, producción y recepción de manera simultánea.

En el mismo sentido aparece el trabajo de la antropóloga Deborah Poole (2000). En Visión, Raza y Modernidad. Una economía visual del mundo andino de imágenes, la autora se pregunta por el rol que las imágenes ocuparon en las formaciones intelectuales y proyectos estéticos andinos en la transición entre el SXIX y el SXX y por el papel que esas imágenes visuales jugaron en la constitución del discurso racial de la modernidad en general. Poole (2000) analiza distintos tipos de materiales y propone para su abordaje la interesante noción de mundo de imágenes. Propone pensar en una economía visual en la cual se sistematizan los campos de la visión que se unen al conjunto de relaciones sociales de poder y a la trama de significaciones de la cual forman parte. En este trabajo, Poole (2000) enfatiza la necesidad de considerar no sólo el valor de uso de las imágenes visuales, es decir, su función más representacional, sino también su valor de cambio, que implica pensar en relaciones de poder y estatus que provoca la posesión de imágenes, complejas transacciones y disputas que los diferentes observadores producen y la relación con distintos mundos de imágenes que se conectas entre sí a través de la circulación de imágenes-objetos. En estos trabajos más recientes lo visual aparece como una dimensión constitutiva de la realidad social y no como un mero reflejo, con el carácter de verdad o realidad que le atribuían los primeros antropólogos a las imágenes.

Parte de esta revisión bibliográfica se debe a un curso que realicé en 2018, titulado Antropología de lo visual, dictado por el Dr. Carlos Masotta en el marco del Doctorado en Ciencias Antropológicas (Facultad de Filosofía y Humanidades - Universidad Nacional de Córdoba. Este acontecimiento fue una oportunidad y el impulso para trabajar de manera específica con el análisis de un corpus de imágenes que forma parte de los registros 
María Daniela Brollo ¿Te puedo sacar una foto?: Producción y circulación de imágenes digitales en el mundo artístico drag queen

fotográficos obtenidos durante mi trabajo de campo etnográfico realizado con artistas drag queens en la ciudad de Córdoba y en la ciudad de San Miguel de Tucumán1.

Las inquietudes que dan lugar a este artículo surgen de las lecturas mencionadas y apuntan a responder la siguiente pregunta: ¿Qué hacemos los/las antropólogos/as con las imágenes? y ¿qué lugar ocupaban las fotografías en el mundo artístico drag queen?

\section{Notas acerca del mundo artístico drag queen}

En este trabajo recurriré a mi pesquisa doctoral centrada en los mundos del arte drag queen y en los procesos de formación de subjetividades que se construyen en torno a estas prácticas artísticas, en contextos nocturnos mercantilizados en la ciudad de Córdoba y en la ciudad de San Miguel de Tucumán ${ }^{2}$. Muchas de las inquietudes de mi investigación se inscriben y surgen del diálogo producido entre un grupo de pesquisas locales que integran un programa de trabajo denominado Sujeciones y Subjetividades contemporáneas, dirigido por el Dr. Gustavo Blázquez y la Dra. María Gabriela Lugones.

La noción de mundos del arte a la que remito de manera constante, fue propuesta por Howard Becker (2008) y me resulta útil a la hora de analizar la dimensión colaborativa de la producción artística drag queen, es decir quiénes y de qué modo participaban en la construcción de un mundo social en tanto mundo artístico, y no tanto las obras de arte en sí mismas (aquello que las artistas hacían en cuanto artistas). Durante mi trabajo de campo pude observar que las producciones llevadas a cabo por artistas drag queens formaban parte de un amplio mundo que incluía relaciones y convenciones en torno al desarrollo de un arte de la performance, la estética y la exhibición escénica de personajes femeninos o andróginos. En ese mundo, las imágenes cobraban gran relevancia y la fotografía como arte y técnica especialmente ya que era el medio privilegiado para mostrar, en un soporte más o menos permanente, aquello que las artistas producían sobre sus cuerpos a través del uso de maquillajes, vestimentas y accesorios.

\footnotetext{
${ }^{1}$ En el presente artículo usaré itálica para resaltar categorías nativas, entrevistas y conversaciones que mantuve con mis interlocutoras y también para términos en inglés. Las citas bibliográficas y categorías teóricas serán introducidas siguiendo el formato Normas APA.

2 Actualmente cuento con una beca doctoral CONICET y me encuentro realizando el Doctorado en Ciencias Antropológicas en la Universidad Nacional de Córdoba. Mi trabajo se titula: "Drag queen" Performances y espacios de (homo)sociabilidad en la Ciudad de Córdoba, y cuenta con la dirección del Dr. Gustavo Blázquez.
} 
María Daniela Brollo ¿Te puedo sacar una foto?: Producción y circulación de imágenes digitales en el mundo artístico drag queen

Para las artistas con quienes trabajé, drag queen era una categoría que incluía un conjunto de técnicas y prácticas artísticas vinculadas a performances de feminidad y transición de roles de género. No me detendré en esta oportunidad en la compleja configuración relacional de las categorías con que se nombraban mis interlocutoras, pero tal cual ellas lo señalaban, en general se trataba de varones que performaban y construían personajes extravagantes y exagerados con distintos grados de femeneidad o androginia, en una duración temporal efímera de entre tres y ocho horas. Las prácticas artísticas drag queens incluían la preparación estética y corporal propia a través del maquillaje y el vestuario, la realización de coreografías, monólogos humorísticos, shows, bailes y actuaciones sobre un escenario, y la presencia en espacios nocturnos mercantilizados como discos, boliches, bares, fiestas y teatros, en los cuales eran contratadas o convocadas para generar una atracción y entretener al público de dichos eventos.

Esther Newton (2016 [1972]), en su pionera etnografía con transformistas femeninos estadounidenses, señaló que «[...] el drag quiere decir, en primer lugar, 'juego de roles' (...) el término está ligado a los accesorios de la apariencia externa de un rol» (p.154). En el trabajo con las apariencias, las drag queens construían sus personajes a través de la cita y la reiteración, procesos propios de la performance como algo hecho siempre por segunda vez. Recurro a la noción de performance desde la propuesta proveniente del trabajo de Richard Schechner (2000), quien propone la posibilidad de estudiar performances propiamente dichas por un lado, y la opción de pensar situaciones sociales como si fuesen performances. Este lente teórico-metodológico me permitió considerar las perfomances drag queens más allá de su duración estipulada, es decir un show en particular o la estadía de las artistas en la disco, incluyendo tanto la preparación previa como las reacciones posteriores. De este modo pude incorporar en mi análisis el circuito virtual on-line posterior que se superponía con aquello que yo observaba off-line durante la noche, e incluso me permitió pensar la extensión espaciotemporal de aquella noche en formato virtual a partir de la circulación de fotografías que analizaré más adelante.

En palabras de Diana Taylor (2011) «[...] la palabra performance nos permite aludir tanto a la hipervisibilidad de la teatralidad como al sistema de mediatización del espectáculo, y a la vez dar cuenta de la acción y la resistencia humana [...] teatralidad y espectáculo son sustantivos sin verbo. No dan lugar a la noción de respuesta o resistencia individual» (p.47). Tal como propone la autora, mientras la teatralidad resalta el carácter artificial, eficaz y construido de un acto, el espectáculo resalta aquello que se exhibe y el modo en que se muestra. A esta definición podemos adherir la referencia de Guy Debord (2005), según el cual la noción de espectáculo refiere directamente a la sociedad moderna y postindustrial y nos permite pensar 
María Daniela Brollo ¿Te puedo sacar una foto?: Producción y circulación de imágenes digitales en el mundo artístico drag queen

de qué modo operan las maquinarias de visibilidad en contextos de consumismo y globalización. Desde esta óptica, donde el término performance adhiere la dimensión de agencia, podemos afinar el objetivo de este trabajo y preguntarnos: ¿cuáles eran las dinámicas de visibilidad en el mundo artístico drag queen? y ¿cómo se mediatizaban las performances observadas?

Si pensamos a las imágenes como procesos bifrontes y polisémicos, es posible analizar el lugar de mediación que ocupaban ciertas imágenes en el caso de la cita y la elección de referencias en las producciones drag queens. La corporalidad que las drag queens construían con sus personajes se producía a partir de prácticas específicas como el maquillaje, el manejo de la actuación escénica y la utilización de vestimentas específicas, pelucas o cascos, zapatos con tacos altos o plataformas en los pies. Ese conjunto de prácticas era señalado por sus protagonistas como un tipo de montaje, más bien, montarse o estar montada eran verbos con una carga semántica que incluía el tránsito, los actos y las acciones llevadas a cabo sobre el cuerpo para dar vida a los personajes que encarnaban. En ese proceso, las artistas citaban elementos extraídos de múltiples imágenes -no sólo- de mujeres o personajes cinematográficos a los cuales elegían por determinados atributos a partir de la observación, superponiendo así una secuencia de referencias sobre el propio cuerpo en relación a la morfología del rostro, al tipo de cabello, al estilo de vestuario y a las actitudes. En este sentido, y teniendo en cuenta el proceso de citación señalado más arriba, podría pensarse cierta asociación entre el montaje drag queen y el montaje en tanto técnica cinematográfica o fotográfica en donde, como propone Mirzoeff (2003), se proporciona una coyuntura artificial de dos o más puntos de vista, o dos o más imágenes para la creación de otra(s). En el montaje drag queen las artistas sobre su propia imagen citaban otros rostros, cuerpos y estilos a partir de imágenes de artistas a las cuales admiraban como divas nacionales del teatro de revista, de la televisión del mundo del espectáculo, del cine o cantantes famosas del ámbito nacional e internacional. Sos un poco de cada una y ahí armas tu estilo propio, me dijo una noche una artista con la cual conversábamos sobre las referencias elegidas para la construcción de sus personajes.

Una de las prácticas más importantes al montarse era la realización del make-up o maquillaje. Este momento era señalado por las artistas como una ceremonia y en ese momento circulaban o se comentaban, a través de soportes como celulares o computadoras, muchas imágenes como las que serán analizadas en este trabajo. El maquillaje se realizaba durante los momentos previos a las performances, las artistas se sentaban frente a un espejo con todos sus materiales a mano, listas para borrar el rostro y volverlo a dibujar, tal como lo decían ellas. En ese nuevo diseño facial realizaban un proceso de carácter mimético en el cual (re)producían 
María Daniela Brollo ¿Te puedo sacar una foto?: Producción y circulación de imágenes digitales en el mundo artístico drag queen

atributos femeninos sobre un rostro que percibían como masculino. En función de sus preferencias estilísticas variaban por ejemplo, las tonalidades de base de maquillaje, combinaciones de sombras de ojos, tipos de lentes de contacto, colores y tamaños de cejas o pestañas, utilización de accesorios como piedras o gemas adheridas sobre la piel y forma o tamaño de labios.

En el proceso de aprendizaje o perfeccionamiento de técnicas como el maquillaje, las artistas requerían de la co-presencia con un grupo de pares de las cuales aprendían minuciosamente los trucos del oficio. Esto sucedía en los camarines durante la previa pero también en talleres 0 cursos especializados. Sin embargo, en los últimos diez o quince años y por las innovaciones tecnológicas ya mencionadas, los soportes audio-visuales comenzaron a ganar protagonismo en este proceso de transmisión de conocimientos, a partir del incremento de productos protagonizados o creados por artistas drag queen. Por un lado, una gran cantidad de videos o fotografías circulaban en plataformas virtuales como Facebook, Instagram o Youtube. Estas redes sociales virtuales se tornaron de uso masivo en 2010 aproximadamente. Para su uso, requieren un aparato con acceso a Internet, como celulares o computadoras, y permiten compartir distinto tipo de contenido visual entre sus miembros. Dentro de los videos más difundidos se encontraban los tutoriales, en los cuales algunas artistas con experiencia enseñaban y mostraban los pasos a seguir para iniciarse o perfeccionar las técnicas de maquillaje, vestimenta y actuación. Por otro lado, las artistas mencionaban el aumento de productos audiovisuales que incluían drag queens como protagonistas ya sea en formato de películas o series, y reality-shows o certámenes popularizados como el caso estadounidense RuPaul's Drag Race.

Los dispositivos digitales como los celulares inteligentes, o Smartphones que permiten manipular las redes sociales mediante aplicaciones, modificaron muchas de las prácticas que las artistas con mayor trayectoria realizaban veinte años atrás como parte de sus actividades profesionales. Ahora es diferente, pero cuando nosotras empezamos, hace veinte años, no existía internet, ni youtube, ni nada de eso, para conocernos tenías que venir a vernos mencionaba Antara, una artista drag queen cordobesa, refiriéndose al impacto de las vertiginosas transformaciones tecnológicas. Tal cual sostiene Triquell (2011), en las últimas décadas se han re inventado los guiones que dan sentido a las experiencias narradas y las redes sociales son uno de los mayores exponentes. En el mundo artístico drag queen las fotografías comenzaron a tener cada vez más protagonismo ya que se trataba de una actividad fundamentalmente visual que resaltaba aspectos estéticos vinculados a la exhibición corporal. Atendiendo a la relevancia que las imágenes adquirían en el universo social pesquisado, el objetivo de este artículo apuntará hacia un abordaje etnográfico de la relación entre la práctica 
María Daniela Brollo ¿Te puedo sacar una foto?: Producción y circulación de imágenes digitales en el mundo artístico drag queen

artística drag queen y las imágenes, a través del análisis de la producción y circulación de fotografías digitales en redes sociales virtuales.

\section{La performatividad de las fotografías}

Durante mis primeros acercamientos al mundo artístico drag queen comencé a notar el protagonismo que adquirían las fotografías en los distintos espacios y el nivel de proximidad en que se mantenían fotógrafos/as y artistas. Como antropóloga y observadora, rápidamente me vi involucrada en esas relaciones sociales de producción de imágenes.

¿Te puedo pedir una foto? era una de las preguntas con que usualmente decenas de personas durante la noche nos acercábamos a las artistas, en mi caso muchas veces fue el modo de entablar un diálogo inicial con mis interlocutoras. Las artistas posaban, ante una, dos o más cámaras con flashes de luces artificiales que apuntaban hacia ellas de manera simultánea. Esta situación duraba algunos minutos, mientras las artistas variaban sus poses corporales frente a la cámara, atentas a la mirada del/a fotógrafo/a mientras alguna que otra curiosa del público se acercaba atraída por las luces.

La 17을 Elección Nacional de la Reina Drag Queen en Tucumán, fue un evento de gran magnificencia para el mundo artístico en cuestión realizado en Diva! Mother House, una disco ubicada en la ciudad de San Miguel de Tucumán, en julio de 2018. Dada la jerarquía de la situación social, aquella noche hubo más de cincuenta artistas drag queens que viajaron desde distintos puntos del país para asistir a la elección. Los flashes de las cámaras que se disparaban en milésimas de segundos, rodeaban constantemente a las artistas mientras que ellas lucían sus mejores y más extravagantes producciones en vestuario y maquillaje (Figuras 1, 2 y 3). Había un sector específico ubicado en la entrada destinado para la toma de fotografías, dispuesto con trípodes fijos y un fondo de tela que las fotógrafas oficiales de la disco utilizaron para registrar la llegada de las artistas al evento, al estilo de una gran alfombra roja. Pero las cámaras no se limitaron espacialmente a ese sector y las fotografías se tomaron de manera continua en casi todos los espacios como el patio, la pista de baile y, por supuesto, el escenario. Prácticamente, el público observaba a las artistas a través de una pantalla, y lo mismo hacía yo. 


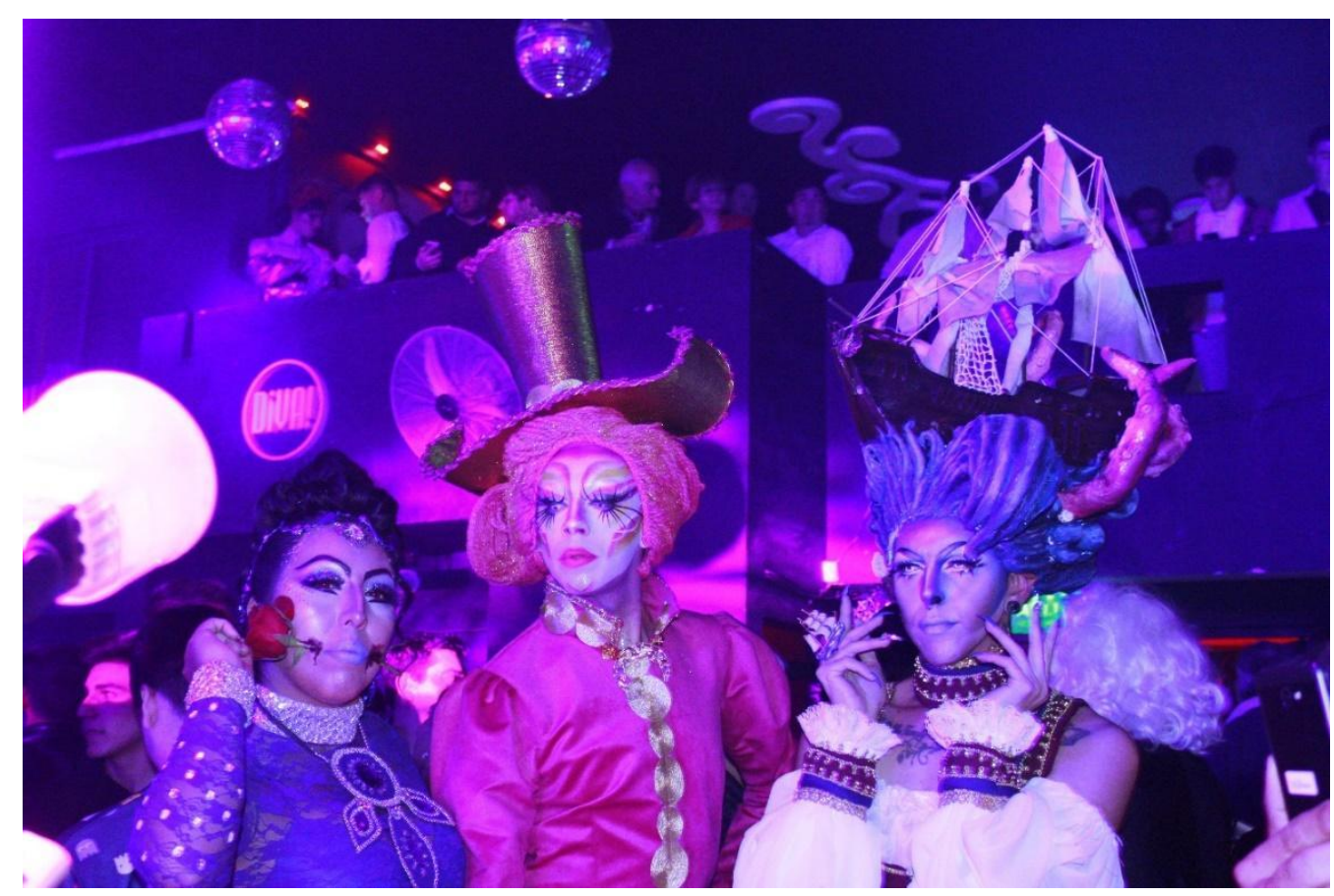

Figura 1: Drag queens posando antes distintas cámaras en simultáneo, 2018, María Daniela Brollo (" $17^{\circ}$ Elección Nacional de la Reina Drag Queen", Diva! MotherHouse, San Miguel de Tucumán, Argentina).

Uno de los intercambios negociados con mis interlocutoras era el registro y la toma de fotografías. En ese momento de mi trabajo de campo, y por mis posibilidades económicas, me había comprado una cámara fotográfica semi-profesional y dada la necesidad de mejorar mi técnica había realizado un curso inicial de fotografía. Aquella noche arribé a la disco con la cámara en mano pero al finalizar el evento me encontré algo frustrada porque mi registro no me parecía de buena calidad, muchas fotografías se encontraban fuera de foco o no tenían un buen encuadre. Edité aquellas pocas imágenes que consideré mejores y las envié a sus protagonistas. Tiempo después, volví a ver las fotografías y encontré interrogantes más interesantes para mí que la calidad o la definición de las imágenes. ¿De qué modo la fotografía devenía una práctica tan relevante en la noche? ¿Cuál era el lugar que las artistas otorgaban a las fotografías? Y ¿Qué imágenes circulaban? 


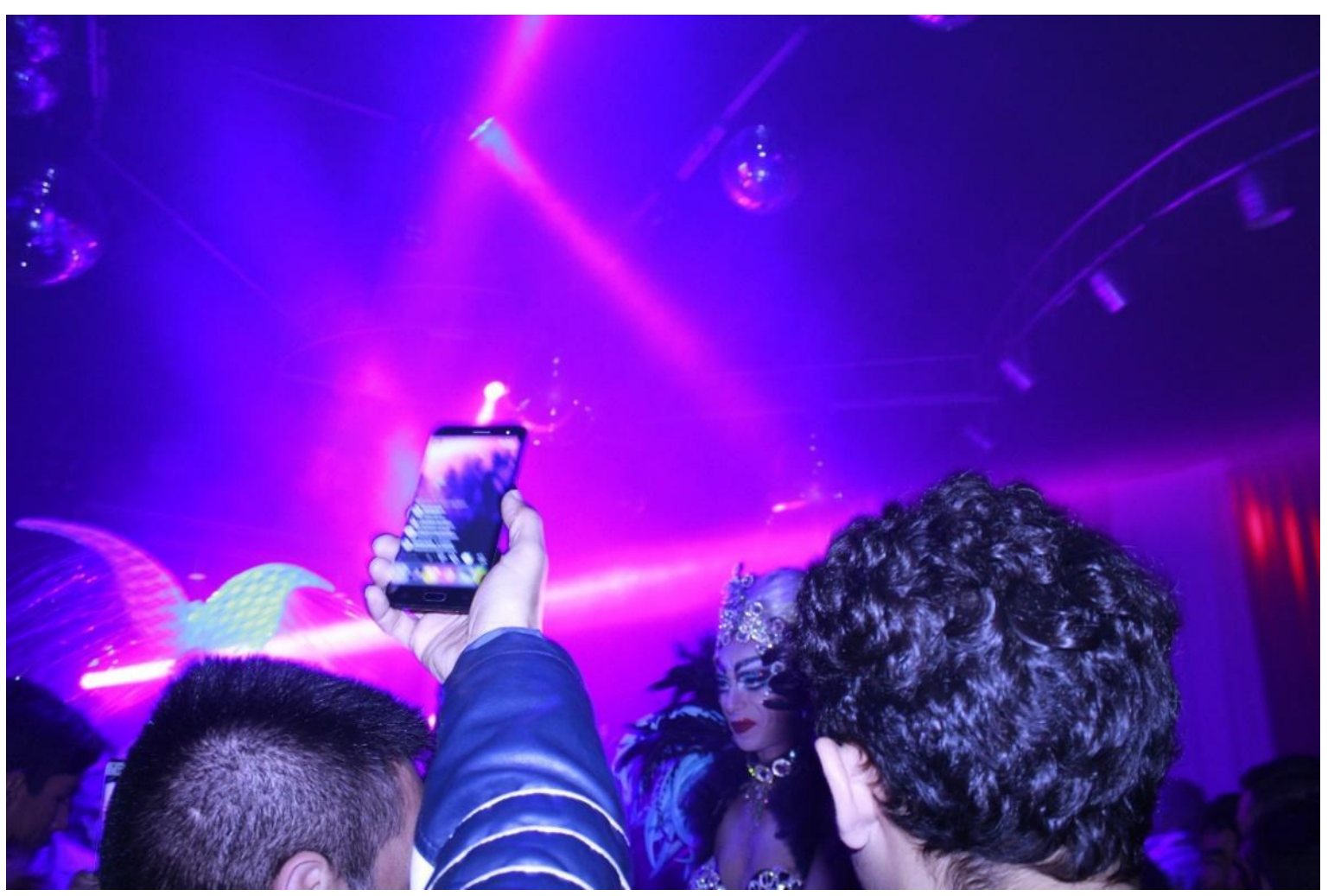

Figura 3: Integrantes del público filmando y fotografiando a Hollywood, 2018, María Daniela Brollo ("17을 Elección Nacional de la Reina Drag Queen”, Diva! MotherHouse, San Miguel de Tucumán, Argentina).

Como dije, durante aquel evento la toma de fotografías protagonizó parte del repertorio de prácticas llevadas a cabo durante las performances y luego devino archivo una vez que gran cantidad de fotografías comenzaron a circular en las redes sociales con posterioridad al evento. Las que ganaron mayor protagonismo fueron aquellas producidas por las fotógrafas oficiales difundidas en la página de Facebook de la disco tucumana. El nivel de protagonismo de estas fotografías lo marcaba la cantidad de veces que estas imágenes, con luces y definición de gran calidad, fueron replicadas en las cuentas personales de las artistas. Las fotografías mostraban a casi todas las participantes e invitadas del evento, con sus producciones, vestuarios y maquillajes, y también contenían el registro de momentos importantes como la entrega de premios a la nueva reina coronada. Este conjunto de imágenes que circulaban en Facebook, con el logo de la disco y una marca de agua con autoría de la fotógrafa, se conformaron de algún modo en el archivo oficial de lo que fue la $17^{\circ}$ Elección Nacional de la Reina Drag Queen Argentina.

Durante las entrevistas que realicé hubo menciones a las fotografías de archivo de las ediciones pasadas de este evento. Sin embargo, era notorio que en el caso de las artistas con 
María Daniela Brollo ¿ Te puedo sacar una foto?: Producción y circulación de imágenes digitales en el mundo artístico drag queen

mayor trayectoria mencionaran la dificultad de contar con ese registro de manera inmediata. Algún día te voy a buscar esas fotos en papel, las debo tener guardadas, me gustaría que las veas, me decía Antara refiriendo a fotografías de la primera elección nacional en el año 2000, cuando la fotografía digital aún no era de uso masivo y la red social Facebook no existía, ya que su primera aparición en español fue en el año 2008.

Durante entrevistas o conversaciones con las artistas más jóvenes, o con menor trayectoria, era usual que me mostraban las producciones que habían utilizado en la elección cinco años atrás ingresando a sus cuentas de Facebook o a la cuenta de la disco tucumana y buscando en los álbumes de fotografías con fecha específica. La creciente masividad de fotografías en redes sociales virtuales permitió que archivos como este puedan ser revisitados constantemente lo cual generó nuevas operaciones narrativas vinculadas al recuerdo.

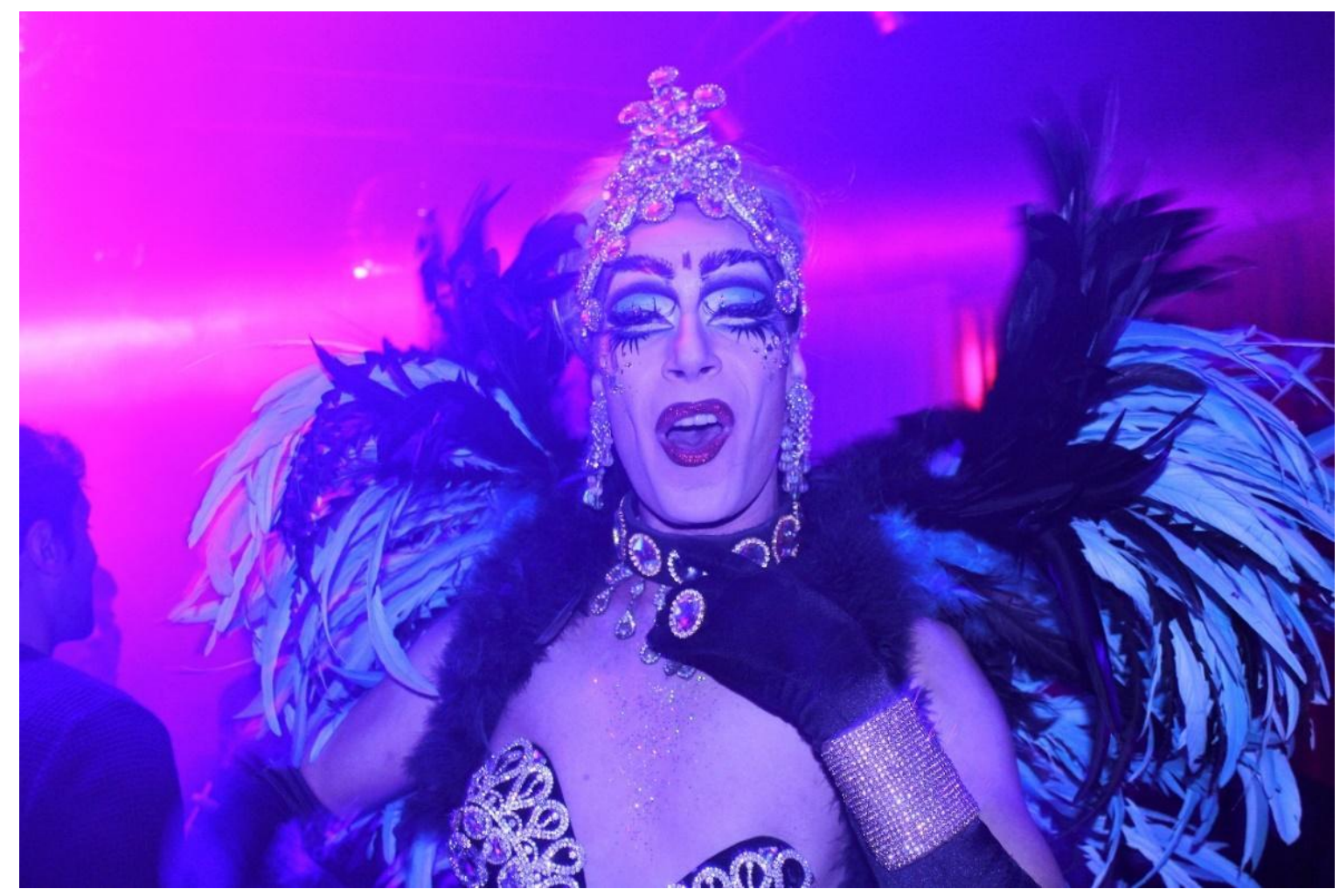

Figura 2: Hollywood bailando y posando ante la cámara, 2018, María Daniela Brollo ("17 Elección Nacional de la Reina Drag Queen”, Diva! MotherHouse, San Miguel de Tucumán, Argentina).

La posibilidad de acceder a fotografías de eventos pasados reconfiguraba los procesos de transmisión de memorias y recuerdos pero además, transformaba la actualización de las convenciones artísticas dentro de ese mundo. "[...] ¿qué cambia si tomamos al repertorio y al 
archivo como formas legítimas de transmisión de conocimiento y memoria colectiva?»(Taylor, 2011). Entendiendo que las fotografías se intercalaban sutilmente entre el repertorio de la performance y el archivo de la misma, la pregunta de Diana Taylor invita a considerarlas como parte de un proceso amplio y dinámico que incluía, a través de la reiteración de imágenes, la configuración de la memoria colectiva del conjunto de artistas drag queens regionales, y a su vez participaba de procesos de transmisión de conocimientos mostrando quiénes eran esas artistas, cuál era su reconocimiento dentro de aquel mundo y cuáles eran sus producciones. Las artistas con mayor status eran más fotografiadas que otras con menos. Sin embargo, eventos como la elección nacional eran una oportunidad para sorprender con una gran producción y ganar así el protagonismo de las cámaras y las miradas del público. Además, la posterior circulación de estas fotografías habilitaba evaluaciones sobre la estética permitiendo a las artistas re-configurar su propia producción en función de las performances que otras drag queens mostraban, por ejemplo a partir de la observación de tendencias de estilo o prácticas que caían en desuso y ya casi no se mostraban.

Estas imágenes, tomadas durante la noche y con el foco puesto en las corporalidades drag queens, integraban las disputas sobre los estereotipos (Burke, 2005) y los códigos que regulaban las maneras de estar, mostrar, mirar e interactuar en esos universos sociales nocturnos. Para las artistas no era una opción pasar desapercibidas y las fotografías materializaban los momentos en que el foco de la percepción estaba puesto en ellas. Sontag (2012) propone que, con su propio código visual, las fotografías alteran y amplían nuestras nociones de lo que merece la pena mirar y de lo que tenemos derecho a observar. En este caso, los códigos visuales que guionaban la práctica fotográfica tenían que ver con ciertas poses corporales que favorecían la exhibición del montaje corporal. Los primeros planos reforzaban la exhibición del rostro y las técnicas de maquillaje aplicadas, mientras que los planos frontales de cuerpo entero permitían observar la producción total del cuerpo, y destacar detalles del vestuario o el calzado. 


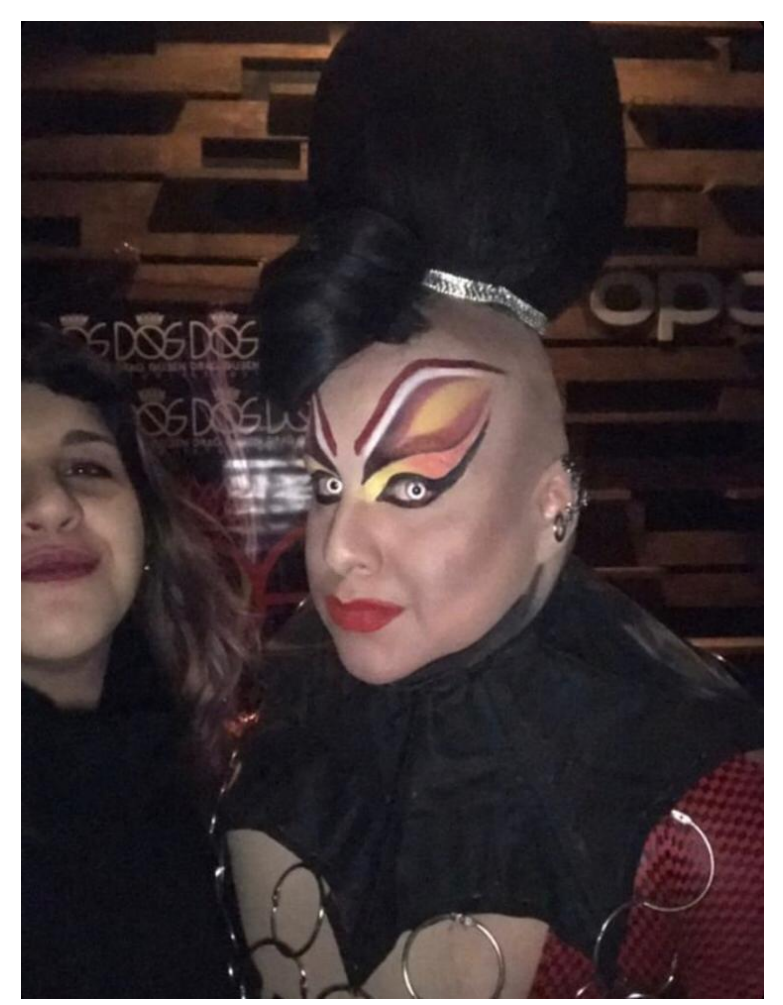

Figura 4. Selfie con Noxema, 2019, María Daniela Brollo (Europa Disco, Córdoba)

En varios momentos de la noche las artistas drag queens se fotografiaban a sí mismas, solas o acompañadas por alguna de sus pares o amigas. Este tipo de fotografía se conocía como selfie, una auto-fotografía cuya popularidad aumentó con el auge en la utilización de redes sociales virtuales en Internet.

Arriba o abajo del escenario las artistas o sus acompañantes sostenían con una de sus manos un teléfono celular, activaban la cámara frontal del aparato lo cual permitía observar la toma y extendían el brazo para alejar la toma en plano picado (brazo elevado hacia arriba cuarenta y cinco grados, de manera que el rostro tomaba mayor protagonismo en la imagen mientras la cámara se mantenía alejada). Posaban realizando diversos gestos faciales, generalmente estirando labios hacia adelante y destacando la mirada. La selfie permitía un mayor control sobre la fotografía, ya que coincidían fotógrafa y fotografiada, y en caso de reprobar la imagen obtenida podían realizarse cuantas tomas quisieran, una y otra vez. Este control aparente, o pretendido, de la selfie permite indagar en la dimensión de cuidado que las artistas drag queens aplicaban a sus fotografías. Siguiendo un planteo de Sontag (2012) sobre la idealización de las imágenes, la fotografía sería aquella imagen donde se pretende que las personas luzcan mejor que nunca. La selfie con Noxema, una drag queen cordobesa (Figura 4) 
tuvo 4 tomas diferentes y ésta fue la elegida. Los recaudos apuntaban a que la toma no desfavoreciera la visual de la producción en maquillaje y vestuario que llevaban la artista, ya que de ese modo podría no tener el impacto positivo esperado en las redes sociales.

Una vez lograda la imagen deseada, la dueña del teléfono celular optaba por publicar la fotografía en alguna de sus redes sociales virtuales y en caso de que en la imagen hubiera otras personas, les enviaba la fotografía para que éstas pudieran manipular la imagen desde sus propios teléfonos. La selfie implicaba la participación directa de las artistas, esta vez como productoras, en ese circuito de fotografías. Esto se vinculaba con una de las características del oficio drag queen, en el cual la autogestión era un valor resaltado por sus protagonistas ya que las artistas se producían a sí mismas. En los boliches y discos no siempre había una fotógrafa oficial como en el caso tucumano descripto anteriormente, entonces la selfie cobraba valor en esa matriz autogestiva en la cual las drag queens devenían artistas que, con un nombre y una imagen, trabajaban constantemente por mantener reconocimiento y visibilidad en ese ambiente. Si pensamos en el mundo de imágenes que propone Poole (2000), resultan relevantes las modificaciones que implicó la posibilidad de participar como productoras de sí, al poner en circulación estas auto-fotografías en las redes sociales.

En el mundo artístico drag queen, como en otros mundos artísticos vinculados al espectáculo, la permanencia era uno de los requerimientos para la movilidad, el reconocimiento y el cambio de status en las carreras artísticas. Las artistas se montaban y participaban de la escena nocturna semanalmente (al menos jueves, viernes y sábado) para mantenerse en el ambiente, asistían a los boliches a realizar shows, a observar a alguna de sus compañeras o simplemente a bailar. Si con las fotografías digitales en general daban cuenta de sus actividades, con las selfies, participaban activamente en la producción de la imagen de sí.

Estar ahí, en la noche, garantizaba la permanencia en el ambiente y las fotografías eran la evidencia material que quedaba, el rastro. La posibilidad de capturar el minuto a minuto de una noche modificó los modos de construir por un lado, esas mismas noches, y por otro lado las carreras artísticas drag queen, ya que reveló algunos aspectos sobre la dimensión económica de esos códigos visuales que se encuentran constantemente en tensión y son altamente dinámicos, como hemos visto.

\section{Las fotografías como recurso}

Desde el momento en que las artistas drag queens comenzaron a invertir en la producción y el cuidado de sus perfiles en Facebook e Instagram, estas plataformas se transformaron en un 
María Daniela Brollo ¿Te puedo sacar una foto?: Producción y circulación de imágenes digitales en el mundo artístico drag queen

espacio de visibilidad para la actividad artística y devinieron un espacio de variados intercambios.

Como vimos, parte de la performance implicaba, para las artistas, exhibirse ante el público al cual debían entretener y su gestualidad estaba fuertemente vinculada con la pose y la búsqueda incesante de la mirada. Tal cual analizan Estalella y Ardévol (2010) para el caso de los rituales de casamientos, las performances drag queen devinieron eventos mediatizados tanto en su puesta en escena como en sus repercusiones posteriores.

Una noche durante el trabajo de campo, en una disco cordobesa, salí a fumar un cigarrillo al patio, me encontré con Noxema y ella me propuso: vení, nos saquemos una foto. Le acercó su teléfono celular a una persona que estaba a mi izquierda y le pidió que nos tome una fotografía. Luego se acercó nuevamente a mí, mirando fijamente hacia la cámara de su celular, me agarró de la cintura, posamos quietas, algo sonrientes, mirando hacia la cámara hasta que se disparó la luz del flash. Al chico no lo conocíamos ni ella ni yo, pero era una interacción habitual pedirle a alguien la toma de una fotografía para mantener una visual de cuerpo entero, algo que la selfie mostrada en el apartado anterior no permitía, ya que seccionaba el cuerpo y sólo permitía mostrar el rostro o la parte superior del torso.

Luego de tomar la foto el chico le devolvió el celular y Noxema le agradeció. Mientras caminábamos de regreso a la pista, Noxema observaba la foto, me invitó a hacer lo mismo para ver si la aprobaba, acto seguido ingresó desde el teléfono a la red social Facebook para subir la imagen. Subir la fotografía implicaba adjuntar la imagen digital en su cuenta personal de Facebook, de modo tal que las personas con las cuales Noxema se vinculaba on-line, pudiesen observar la imagen y saber que ella estaba allí, en Europa Disco y montada de ese modo. Durante aquella noche y al día siguiente inclusive, en el inicio de mi cuenta de Facebook pude ver que, al igual que Noxema, cerca de quince drag queens, subieron fotos en grupo, en pareja o solas en la disco.

Las fotografías digitales se introdujeron como una de las prácticas de mediación en ese vínculo entre artistas y el público. Pensar la dimensión comunicativa de acontecimientos visuales (Mirzoeff, 2003) como el que describí, implica preguntarnos seriamente por el recorrido y los circuitos que estas fotografías realizaban. Una vez en Facebook, las interacciones continuaban. Las fotografías eran depositarias de un sinfín de reacciones por parte de sus observadores. La red social Facebook habilita la opción Me gusta en caso de expresar agrado hacia la imagen, permite la acción Compartir y en ese caso multiplicar o replicar en la cuenta propia la imagen digital o publicación de otra cuenta, y permite también Comentar adhiriendo texto o imágenes a la fotografía.

Question, Vol. 1, N. ${ }^{\circ}$ 65, abril 2020. ISSN 1669-6581

Instituto de Investigaciones en Comunicación | Facultad de Periodismo y Comunicación Social | Universidad Nacional de La Plata La Plata | Buenos Aires | Argentina

Página 16 de 20 
Las artistas se mantenían pendientes de las reacciones en Facebook y pasado algún tiempo inclusive repetían la publicación de fotografías anteriores para mantenerlas visibles y vigentes en sus redes. Estas fotografías eran comentadas por sus pares o por el público con algún tipo de evaluación estética o expresión afectiva sobre la producción que llevaban aquella noche. Sos un fuego o anoche lo diste todo, solían ser algunas de las frases con las comentaban las imágenes. No lo digo yo, me lo dicen. Gracias publico hermoso!!!, era otro de los epígrafes de una de las fotografías que circulaban en las redes. Esta secuencia de interacciones daba a las artistas la posibilidad de que una mayor cantidad de personas las conociera, gustara de su producción y de ese modo ellas aumentaran su popularidad con la posibilidad de conseguir alguna oferta laboral en el futuro. Además, la red social Facebook permite la opción de que los usuarios se etiqueten entre sí, a través de una imagen (o texto) mediante la cual una cuenta personal puede aparecer enlazada en otra. Esto habilitaba para las artistas la extensión del campo de visibilidad de sus imágenes, aparecer en nuevas cuentas de Facebook contribuía a legitimar la (fundamental) relación con su público y también mantener cierta posición en aquel universo social.

Las fotografías digitales producidas en estas noches adquirían valor de cambio, en términos de Poole (2000) y para las artistas, las fotografías formaban parte del circuito de (re)producción de sus personajes. Mediante las imágenes comunicaban algo su público y participaban de un circuito de intercambios donde también esperaban recibir algo a cambio como por ejemplo aumentar el número de seguidores o comentarios de aliento, aprobación y afecto.

\section{Destellos finales}

Desde que comencé el trabajo de campo tuve muchas inquietudes en relación a las modalidades de registro y me pregunté sobre los alcances y limitaciones de incluir el registro audiovisual y fotográfico. Poseo un teléfono celular con cámara fotográfica, por lo cual muchas veces opté por fotografiar o filmar las performances drag queens sin más objetivo inmediato que el registro en sí mismo. Sin embargo, esa práctica se tornó parte de mi análisis reflexivo y decidí comenzar un curso inicial de fotografía y adquirir una cámara profesional. Asistí a varios eventos nocturnos con la cámara en mano y de ese modo comencé a notar que la insistencia con que las artistas me pedían que les tomara fotografías o posaban directamente sin mediación verbal de por medio. Introducirme en el manejo de una cámara fotográfica y experimentar, del otro lado del lente, el valor que las drag queens le asignaban a las imágenes, me permitió dar lugar a los interrogantes que fueron tratados en el presente texto. 
María Daniela Brollo ¿Te puedo sacar una foto?: Producción y circulación de imágenes digitales en el mundo artístico drag queen

Este abordaje metodológico y epistemológico del tratamiento de imágenes sigue, de manera muy inicial al menos, el planteo de Triquell (2016) sobre la necesidad de incorporar la imagen como materia misma de la producción académica. Según propone Henley (2001) entre algunos sectores de la comunidad antropológica circula la idea de que ni el cine ni la fotografía serían actividades académicas genuinamente serias. No sólo debemos como profesionales replantearnos ese viejo prejuicio, sino además preguntarnos qué hacemos con la importancia que el cine y la fotografía (o los medios visuales de comunicación en general) tienen en la vida de nuestros interlocutores.

Una noche, cámara en mano, le pregunte a una artista drag queen tucumana si podía tomarle una fotografía. Claro que sí, querida, para eso estamos me respondió. Esta frase quedó dando vueltas en mi cabeza un largo tiempo. Primero me replanteé mi actitud como etnógrafa y sentí cierta vergüenza por creer que estaba preguntando algo obvio. Luego, siguiendo la apuesta de la disciplina respecto a episodios controversiales, re-signifiqué aquella interacción y la transformé en la indagación del lugar que tenía la fotografía en aquel universo, donde las artistas esperaban que ese registro suceda.

Analizar las prácticas artísticas vinculadas a la producción de imágenes me permitió acceder a narrativas históricas sobre la relevancia que adquirió la fotografía digital en el universo social pesquisado. Tal cual lo mencionaron mis entrevistadas, al menos en los últimos quince años, la producción y circulación de imágenes comenzó a formar parte de las prácticas involucradas en el arte drag queen y dadas las constantes innovaciones tecnológicas, los medios digitales y las redes sociales virtuales se transformaron en el espacio privilegiado de este proceso.

Fotógrafos oficiales del boliche o el teatro, integrantes del público y amigas se acercaban a las artistas para conversar, bailar y muchas veces con la intención de fotografiar a las artistas. Además, las artistas también se retrataban a sí mismas a través de las selfies. Estas imágenes luego iniciaban un circuito en las redes sociales donde devenían un espacio de extensión de la noche a través de la actualización de vínculos afectivos de amistad (o enemistad en algunos casos). Esto me permitió analizar una dimensión social en la cual la fotografía creaba y afianzaba vínculos entre las artistas y su público, que eran fundamentales para la obtención de algún grado de reconocimiento que les permitiera aumentar popularidad.

De este modo, el circuito de imágenes permitía mayor difusión de la actividad profesional y de las producciones para las cuales tanto trabajaban las drag queens. Las fotografías mostraban un primer plano del rostro o cuerpo entero, ya que así las artistas lograban exhibir las técnicas de maquillaje aplicadas sobre la cara o los exuberantes indumentos y accesorios que llevaban puestos. Además, la circulación on-line de estas imágenes fotográficas ponía en movimiento un conjunto de experiencias compartidas vinculadas, entre otros aspectos, a lo estético. Las 
artistas miraban a otras, eran miradas por otras y al mostrarse no sólo exhibían su producción sino también compartían criterios de belleza y se citaban constantemente a través de la crítica o el elogio, en procesos de mutua enseñanza y aprendizaje.

Las escenas aquí analizadas son factibles de ser pensadas en su dimensión más constitutiva ya que, tal cual propone Mirzoeff (2003), la cultura visual en tanto práctica cultural forma parte la subjetividad de los sujetos. Las fotografías eran algo de lo cual se hablaba mucho y algo que requería inversión tanto en su producción como en su circulación. El flash de las cámaras en la noche arrojaba un destello en forma brillo que literalmente resaltaba a las artistas del resto del entorno, algo que ellas deseaban en el espíritu escénico del arte drag queen.

Mi intención en este trabajo fue analizar una práctica como la fotografía, no tanto desde la semiótica de su contenido sino desde los usos y efectos que la práctica fotográfica tenía. Así fue que pude acercarme a una interpretación acerca de los significados que, para las artistas con las que trabajé, tenían la mirada, la exhibición y la difusión de la imagen de sí. Y también, el modo en que esto se volvió con el correr de los años en un recurso, en términos de Yúdice (2002), con el cual mantener una determinada posición o status. Tanto para las artistas respecto de sus relaciones jerarquizadas, como para mí misma en mi posición de etnógrafa.

\section{Referencias bibliográficas}

Becker, H. (2008). Los mundos del arte. Sociología del trabajo artístico. Universidad Nacional de Quilmes, Quilmes, Argentina: Bernal.

Burke, P. 2005. "Estereotipo de los otros" En: Visto y no visto. Usos de la imagen como documento histórico. Barcelona: Crítica.

Debord, G. (2005) La sociedad del espectáculo. Editorial: Pre-textos.

Estalella, A. y Ardévol, E. (2010). Internet: instrumento de investigación y campo de estudio para la antropología visual. En: Revista Chilena de Antropología Visual - número 15Santiago. ISSN 0718-876.

Henley, P. (2001). Cine etnográfico: tecnología, práctica y teoría antropológica.Desacatos $8, \quad$ pp. 17-36. Recuperado de: http://www.scielo.org.mx/scielo.php?script=sci abstract\&pid=S1607050X2001000300002\&lng= es\&nrm=iso

Mitchell,W.J.T (2009 [1994]). Teoría de la imagen. Ensayos sobre representación verbal y visual. Traducción Yaiza Hernandez Velázquez. España, Madrid: Ediciones Akal. 
María Daniela Brollo ¿Te puedo sacar una foto?: Producción y circulación de imágenes digitales en el mundo artístico drag queen

Masotta, C. (1995). Antropología para Ver. Sobre el uso de imágenes en la primera Antropología. Revista Causas y Azares, Año II, Número 2. Recuperado de: http://www.ahira.com.ar/ejemplares/causas-y-azares-no-2/

Mirzoeff, N. (2003 [1999]). Introducción. ¿Qué es la cultura visual? En: Una introducción a la cultura visual. Buenos Aires, Argentina: Paidós.

Newton, E. (2016 [1972]). Mother Camp. Un estudio de los transformistas femeninos en los Estados Unidos. Edición de María José Bullejos

Poole, D. (2000). Introducción. En: Poole D. Visión, Raza y Modernidad. Una economía visual del mundo andino de imágenes (pp. 11- 35). Lima, Perú: Casa de estudios del socialismo.

Ruby, J. (2007). Los últimos 20 años de Antropología visual - una revisión crítica. Revista Chilena de Antropología Visual, № 9. Recuperado de: http://www.antropologiavisual.cl/imagenes9/imprimr/ruby.pdf

Sontag, S. (2012). Sobre la Fotografía. Editorial: De Bolsillo.

Sívori, H. (2005). Locas, chongos y gays. Sociabilidad homosexual masculina durante ladécada de 1990. Buenos Aires: Antropofagia.

Taylor, D. (2011). Introducción. Performance, teoría y práctica. En Taylor, Diana y Marcela A. Fuentes (Ed.). Estudios avanzados de Performance. México DF, México: Fondo de Cultura Económica.

Triquell, A. (2011). Imágenes que (nos) miran Experiencia, visualidad e identidad narrativa. Prácticas de oficio. Investigación y reflexión en Ciencias Sociales, n 7/8. Recuperado de: https://ides.org.ar/wp-content/uploads/2012/04/artic51.pdf (2016). Hacer (lo) visible la imagen fotográfica en la investigación social. Revista Reflexiones 94 (2), 121-32. Recuperado de: https://revistas.ucr.ac.cr/index.php/reflexiones/article/view/25462

Yúdice, G. (2002). El recurso de la cultura. Usos de la cultura en la era global. España, Barcelona: Gedisa. 